\title{
FRIDAY PRAYER AND AN INDONESIAN ISLAMIC IDENTITY IN CANBERRA, AUSTRALIA
}

\author{
Syamsul Rijal \\ The Australian National University (ANU), Canberra
}

\begin{abstract}
This paper analyses the meaning of Friday prayer for Indonesian Muslims students in Canberra, Australia. Due to the nature of obligatory prayer (s d la in Islam, it is hard to identify the symbolic meaning of every movement of prayer for the Muslim participants. However, using Bowen's analysis, this paper emphasizes the social significance of Friday prayer for its participants in a particular place and time. It argues that Friday prayer is viewed by Indonesian Muslim participants as a medium to strengthen their Islamic faith and their membership of the Indonesian Islamic community in Canberra. Being a minority group, facing a prevailing Western culture, they try to maintain their faith and create social cohesion among Indonesian Muslims through their participation in this Islamic ritual.
\end{abstract}

Keywords: Indonesian Islamic identity, Friday prayer, Muslim minorities.

\section{Introduction}

The academic study of the Islamic ritual of worship (sdla has not attracted much attention, especially from an anthropological perspective. ${ }^{1}$ Despite its centrality to Muslim religious life, the discussion of stras has been confined to the realm of Islamic legal law (fiqh). It is viewed by Muslims as something fixed, with no need for further

\footnotetext{
${ }^{1}$ See John R. Bowen, "Salat in Indonesia: The Social Meanings of an Islamic Ritual," in John R. Bowen (ed.), Religion in Culture and Society (Boston: Allyn and Bacon, 1998); Marion H. Katz, "The Study of Islamic Ritual and the Meaning of Wudu," Der Islam, No. 82 (2005), pp. 106-145; Andre Moller, "Islam and Traweh Prayers in Java: Unity, Diversity, and Cultural Smoothness," Indonesia and the Malay World, Vol. 33, No. 95 (2005), pp. 37-52.
} 
examination. Denny wrote that "the systematic study of ritual within traditional Islamic studies has been recessive." In fact, anthropologists and Islamicists, who predominantly come from Western academia, have been more interested in rituals regarded as un-Islamic and locally distinctive. In the words of Bowen, they "have neglected 'ordinary' Islamic rituals as having more to do with a 'Great Tradition' than with local social meanings." 3 Geertz, for example studied slametan, a local Islamic ritual in Java. Modernist Muslims do not consider this ritual Islamic as it has no theological reference, either in the Qur'a $\$$ or the Prophetic traditions. Geertz successfully argued that the symbols of meaning in slametan were based on Javanese traditions. ${ }^{4}$ Nonetheless, it would be difficult for anthropologists to apply Geertz's thesis to ordinary Islamic worship.

The difficulty in studying the meaning of ordinary Islamic ritual, especially sflaf lies in the fact that Muslims directly apply the model of worship used by the Prophet himself. Indeed, Muslims are forbidden to make modifications to sflas What is important is to practice what has been commanded by God and His Prophet. In relation to Islamic ritual, Hawting may be right to argue that "Muslims, like Jews, express their adherence to their religion mainly by performance of required religious rituals, regularly repeated and involving prescribed words and actions." This is different from Christians who emphasize acceptance of religious beliefs and dogma as indicative of their religious identity. Therefore, the conviction that Islam emphasizes orthopraxy more than orthodoxy might have some validity. This conviction leads scholars to

2 Frederick M. Denny, "Islamic Ritual: Perspectives and Theories," in Richard C. Martin (ed.), Approaches to Islam in Religious Studies (Arizona: University of Arizona, 1985), p. 63.

3 Bowen, "Salat in Indonesia," p. 161.

${ }^{4}$ Clifford Geertz, The Religion of Java (Chicago and London: The University of Chicago Press, 1967), pp. 11-15. This outstanding work, however, has been criticized by many scholars as overlooking Islam as a core element in the Javanese Muslim rituals. See for example H. W. Bachtiar, "The Religion of Java: a Commentary," Madjalab Ilmu-Ilmu Sastra Indonesia, Vol. V, No. 1 (1973); Mark Woodward, Islam in Java: Normative Piety and Mysticism in the Sultanate of Yogyakarta (Tucson: The University of Arizone Press, 1989).

5 Sala $>$ refers to the five daily prayers, Friday prayer and any non-obligatory or recommended (sunnat) prayers. It is also referred to as sembabyang in Indonesian. In this paper, shla $\rightarrow$ and prayer are used interchangeably.

${ }^{6}$ Gerald Hawting, The Development of Islamic Ritual (Great Britain: Ashgate, 2006), p. xiv. 
postulate a lack of symbolic meaning in normative Islamic ritual. Graham, for instance, has suggested that "Islamic ritual is not simply lacking in semantic content, but actively and (ironically) meaningfully declines it." 7

Due to the semantic emptiness of normative Islamic ritual, Bowen through his study on sdlasin Indonesia demonstrates that the social significance of Islamic ritual differs across place and time. ${ }^{8}$ Through his analysis of the social meaning of stlas in three different communities: the Acehnese, the Gayo, and the Muslims of Jakarta, Bowen argues that the various meanings of stal $>$ can be seen within spiritual, social, political, and historical discourses.

Drawing on Bowen's approach, this paper will study the social significance of Friday prayer among Indonesian Muslim students in Canberra. Like the five daily prayers, Friday prayer has been neglected by anthropologists. This paper applies Bowen's model and draws upon both deep connection with the participants, as well as participation in Islamic ritual, to enable the anthropologist to reveal the Muslim perspective of shla . In this regard, I benefited from my position as an Indonesian Muslim who regularly takes part in the Friday prayer. In addition to observation of participants, I have undertaken in-depth interviews with an active member of the Indonesian Muslim student community, Fakhri. ${ }^{9}$ This study views Friday prayer as an expression of minority, religious and national identities. It argues that stlasserves as a site for Indonesian Muslims, a Muslim minority in Canberra, to strengthen their religious and national identity.

Joining and practicing Islamic rituals and activities, including Friday prayer, reinforces an individual's membership of the Indonesian Muslim community. Therefore, my analysis is not confined to the ritual itself, but also examines the role of ritual in defining social position. The first section of this paper discusses the nature and position of shlas and Friday prayer in Islam. The second section will examine the case of Friday prayer at the Australian National University Muslim Association (ANUMA) in Canberra. The final section of this paper will

\footnotetext{
7 William A. Graham, "Islam in the Mirror of Ritual," in Islam's Understanding of Itself (Malibu, California, 1983), p. 66.

8 Bowen, "Salat in Indonesia".

${ }^{9}$ Fakhri is a pseudonym used for my informant.
} 
explore the social significance of the ritual in relation to the issue of minorities and the formation of religious and national identity.

\section{Salat and Friday Prayer in Islam}

Sala $>$ has an important position in Islam. Watt considers it the heart of Islamic worship. ${ }^{10}$ It is one of the five pillars of Islam (arkas al-Isla which consist of: verbally testifying to the unity of God and the prophethood of Muhammad (shahatab); performing the five daily prayers (sdals), fasting (show or sifar) in the month of Ramadlan; giving a prescribed proportion of one's income and property for certain defined, charitable, ends (zakal and participating, at least once in one's lifetime, in the annual rituals performed in and around Mecca during the last month of the Muslim year $\left(b d_{j}\right) .{ }^{11}$ These pillars were derived from the Qur'aæand the Prophetic traditions (H\{di $)$. They suggest that to be Muslim is to perform what is stipulated in the pillars of Islam. However, among the Islamic rituals, sllal is the most prevalent since it must be performed five times a day - at dawn, noon, mid-afternoon, sunset, and after dark. Indeed, shlas theologically identifies a Muslim as a believer. Demonstrating this notion, the Prophet Muhammad is reported to have said: "between belief and unbelief lies the performance of sldals" This statement implies that the performance of ritual prayer defines an individual as a believer or Muslim.

As already mentioned, Islamic rituals in Islam especially shla have theological basis either in the Qur'aæ or the Halith. For Muslims, the Qur'a is the actual words of God faithfully repeated by His messenger Muhłmmad while the $\mathrm{H}\{$ dith are a collection of reports about Muhłmmad's statements and actions. ${ }^{13}$ The Hadith supplement the Qur'aæ as the second basic source for guidance and law in the Muslim community. Muslims refer to these sources to justify whether a

\footnotetext{
${ }_{10}$ W. M. Watt, What is Islam? (London and New York: Longman, 1979), p. 185.

${ }^{11}$ Mahmoud M. Ayoub, Islam: Faith and History (Oxford: Oneworld, 2005), pp. 53-54.

${ }^{12}$ See Heiko Henkel, "Between Belief and Unbelief Lies the Performance of Salat: Meaning and Efficacy of a Muslim Ritual," The Journal of Royal Anthropological Institute (N.S) No. 11 (2005), pp. 487-507.

${ }^{13}$ G. P. Makris, Islam in the Middle East: A Living Tradition (Oxford: Blackwell, 2007), pp. 36-39.
} 
ritual is Islamic or not. The Qur'a $\$$ does not provide details of how to perform slita rather it commands Muslim to undertake sqda According to Hasbi Ash Shiddiqi, there are four Qur'anic verses dealing with the obligation of sdla 1 $^{14}$ The verses are translated by Haleem as follows: ${ }^{15}$

"Keep up the prayer, pay the prescribed alms, and bow your heads [in worship] with those who bow theirs." (Qur'aß2: 43).

"Take care to do your prayers, praying in the best way, and stand before God in devotion. If you are in danger, pray when you are safe again, remember God, for He has taught you what you did not know." (Qur'a 2: 238-239)

"After performing the ritual prayer, continue to remember God—standing, sitting, and lying on your sides—and once you are safe, keep u regular prayer, for prayer is obligatory for believers at prescribed times." (Qur'a $\$ 4: 103)$

"Prophet], recite what has been revealed to you of the Scripture; keep up the prayer: prayer restrains outrageous and unacceptable behaviour." (Qur'aæ29: 45).

However, for deeper explanation of the form of stalas the correct movements and recitations involved - Muslims turn to the $\mathrm{H}$ adith. Within the Hadith there are detailed guidelines of qiyala (standing), ruku>(bowing), and sujut(prostration) to help the believers offer their prayer correctly. Rahman, for instance, exemplified one prophetic tradition described by the Prophet's wife 'A'shah: ${ }^{16}$

"God's Messenger used to begin prayer with takbi» (proclaiming Alla Akbar) and the recitation of surat alfath. When he bowed, he neither kept his head up nor bent it down, but kept it between these extremes; when he raised his head after bowing he did not prostrate himself until had stood erect; when he raised his head after prostration he did not prostrate himself again until he was in the proper sitting position."

\footnotetext{
14 T. M. Hasbi Ash Shiddieqy, Pedoman Shalat (Jakarta: Bulan Bintang, 1966), p. 61.

${ }^{15}$ See Abdel Haleem, A New Translation of the Qur'an (New York: Oxford University Press, 2005).

16 Afzalur Rahman, Utility of Prayer (Lahore, Pakistan: Islamic Publications Ltd, 1974), p. 58 .
} 
The stalamust always be preceded by ritual washing known as wudis $>$ a partial washing), or ghusl (washing of the entire body). Wudis $>$ meaning "to make pure" or "radiant," involves washing the face, rinsing the mouth and nostrils, washing the hands and forearms to the elbows, passing one's wet hands over the head, and wiping the feet for Shicites, or alternatively washing the feet up to the ankles for Sunnites. If water is unavailable or too scarce, clean sand or earth may be used. This is called tayammum. Ghusl is used to remove major impurities such as those caused by sexual relations, menstruation, or direct contact with either blood or a dead corpse. ${ }^{17}$

According to Ayoub, sqla prayers are actually a combination of prayer recitation and prayer through formalised movement. As the words of prayer are uttered, worshippers complete a cycle of standing, bowing, standing, prostration, kneeling, prostration, and standing again. Each of these cycles or units of spoken and enacted prayer is called a raka'ah. Each of the five daily prayers consists of a different number of raka'ah. The dawn stlabconsists of two cycles, the noon and midafternoon prayers of four each, the sunset prayer of three, and the night prayers of four. ${ }^{18}$

Sala Consists of both obligatory and the non-obligatory prayers. The obligatory stilasinclude the five daily prayers and Friday prayer. The latter must be performed in congregation, while the former can be performed individually, but it is recommended that they be performed in congregation where possible. The non-obligatory stlatare numerous and include tabizat al masjid (performed when entering a mosque), the tabajjud (performed during the midnight), istikharath (performed when asking for guidance to choose between two alternatives), tawbah

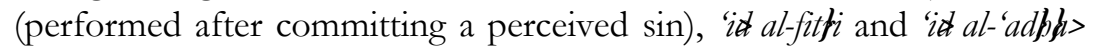
(on the two holidays), istisqa $>$ (when asking for rain to fall), and rawa (before and after obligatory prayers). ${ }^{19}$

The congregational Friday prayer, which is compulsory only for mature men, is held once a week at noon on Friday in the mosque. It is conducted at the time of 2 th

\footnotetext{
17 Ibid.

18 Ibid.

${ }^{19}$ Andre Moller, "Islam and Taraweh Prayers in Java: Unity, Diversity, and Cultural Smoothness," Indonesia and the Malay World, Vol. 33, No. 95 (2005), p. 36.
} 
prayer substitutes the zifhr prayer. According to Ash Shiddiqy, there are two views regarding the naming of stlasal-jum'ah (literally, Friday prayer). The first view suggests that the naming is due to the fact it is performed on Friday. The second view argues that the prayer is called jumu'ah (meaning 'assembly' in Arabic) since it must be performed in congregation. ${ }^{20}$ Despite these contrasting views, the Qur'a clearly encourages Muslims to perform Friday prayer: "O you who believe! When there is a call to worship on Friday, hasten to the remembrance of Allah, and cease selling. That is better for you, if you know" (Qur'aæ. 62: 9).

The Friday prayer ritual differs from daily prayers as it consists of two sermons (khutbah) and two raka'abs. According to Ayoub, the sermons substitute the first two raka'abs of the noon prayer, followed by the remaining two rak'ats which make up of four raka'abs. ${ }^{21}$ Friday prayer khutbah usually deals with religious, moral, and political issues. Whatever the issue, khutbah must follow the obligatory rules for preaching known as arkapal-khutbah (pillars of sermon). Referring to Sha ischool, Hawting lists 5 pillars of khutbah as: the holmd Alla (praise to God), the stras ala >al-nabi>blessing to Prophet), the exhortation to piety (al wasifor bi al taqwa) the prayer for the believers (al-du'a Sli al-mu'mini $\gg$, and recitation from the Qur'a (al-qira $\$)^{22}$ After delivering his sermon, the preacher (khati usually leads sqla In Indonesia, however, some mosques have appointed their own prayer leader (ima). Details of the Friday prayer ritual will be further discussed later as this section aims only to show how Islamic texts deal with sqlas.

Having explored strasin the view of Islamic sources, it becomes apparent that a great deal of emphasis is given to the correct practice of sflas. There is, however, no explanation in either the Qur'a or Hadi detailing the symbolic meaning of the movements involved in prayer. It is generally stated from the sources that strasand other Islamic rituals aim at offering dedication and devotion (ibah) to God as the creator of the universe. Nonetheless, some Muslim scholars

\footnotetext{
20 Ash Shiddieqy, Pedoman Shalat, pp. 417-418.

${ }^{21}$ Ayoub, Islam: Faith and History, p. 58.

22 Gerald Hawting, The Development of Islamic Ritual (Great Britain: Ashgate, 2006), p. 57.
} 
have provided philosophical explanations or "wisdom" (bikmab) for the stalar Rahman, for example, asserts that stalagives personal benefit to Muslims such as punctuality, sense of duty, self-discipline, character building, self-control, patience and perseverance, efficiency and refinement. On a social level, he argues, słla treaches tolerance, unity, and cooperation with members of society. ${ }^{23}$ Another author, Nadwi, explains that sllas "contains an excellent provision for the nourishment of the soul and provides a most valuable defence against the inroads of materialism and God-negligence." 24 Still, these explanations seem to be a hypothetical justification of prayer's benefit and there is little consensus among Muslim scholars. What is clear here is that in matters of worship Islam stresses orthopraxy more than orthodoxy. This is because, to borrow Bowen's words:

"Carrying out the ritual of sflalacorrectly means replicating those acts performed by the Prophet Muhammad that were intended to serve as guides for the Muslim community... Therefore, in matters of worship one should do precisely what Muhammad did - all of it and no more." 25

\section{The Case of Friday Prayer at ANUMA}

ANUMA serves as a small mosque for Muslim students, especially for those who study at ANU Canberra, to pray and participate in Islamic rituals and activities. ANUMA provides space for about 100 Muslims to congregate and pray. In addition to Friday prayer, many Muslim students perform their daily prayers, especially 2$\} \mathrm{kbr}$ (noon) and ${ }^{\prime} a s r^{2}$ (afternoon) prayer at ANUMA. Muslim students also use this space for religious discussion, Qur'anic teaching for children, Islamic holy day celebrations and various other Islamic activities.

Muslim students routinely attend Friday prayer at ANUMA. According to Fakhri, many Muslims, not only students, pray there because it is close to the city and more accessible than the main

23 See Rahman, Utility of Prayer, See also Idem., Prayer: Its Significance and Benefits (Singapore: Pustaka Nasional, 1979).

24 S. Abul Hasan Ali Nadwi, The Four Pillars of Islam (India: Academy of Islamic Research and Publications, 1972), p. 16.

25 John R. Bowen, "Imputations of Faith and Allegiance: Islamic Prayer and Indonesian Politics outside the Mosque," in David Parkin and S. C. Headley (eds.), Islamic Prayer Across the Indonesian Ocean (UK: Curzon, 2000), p. 24. 
mosque in Canberra. The Muslim participants come from various nations and ethnic groups and include people from Arab nations, Indians, Pakistanis, Iranians, Malaysians, and Indonesians.

When arriving at ANUMA for Friday prayer, one often finds Muslims reciting the Qur'aæ. Fakhri usually goes to Friday prayer twenty to thirty minutes before adhan (the call to prayer) so that he has enough time to recite the Qur'a before the prayer. Others perform tahi $>$ al-masjid when entering the mosque. Fakhri explains that although such prayer is not obligatory, it is highly recommended by the Prophet. He goes on to relate the story of when the Prophet was once delivering Friday sermon and one of his companions came late and directly sat without praying tahifal-masjic. The Prophet stopped his sermon asking him to pray first. Therefore, even while the sermon is being delivered, many Muslims carry out the prayer before sitting.

Other people at ANUMA are having a conversation with their friends and others stand in line to take wudi $>>$ Taking wudu $>>$ is a compulsory requirement of Islamic worship. According to my informant, prayer must be performed after wudif $>$ in a state of purity). Islam requires Muslims to keep their body and clothes clean when performing sdlal Especially for Friday prayer, he says, the Prophet encourages Muslims to have a bath, to take wudis $>$ to use perfume and to wear clean and proper clothes. When asked about the meanings behind the steps of wudi $\}>$ he replies that wudi $\}>$ like other rituals, is hard to rationalise. He illustrates this by pointing out that when a male Muslim urinates, passes wind or touches a woman's skin, his wudi $>>$ becomes invalid. Logically, he should only clean the part of the body which invalidated his wudi $>$ However, in Islam, he said, Muslims must perform the entire ablution again, as this is clearly ordered by the Prophet. With regard to clothing, most members of the congregations at ANUMA do not wear "Islamic" clothes as they do in Indonesia. Instead, as many of them wear casual clothes, with some preachers even wearing $\mathrm{t}$-shirts and jackets when delivering khutbah. This is because Islamic clothing is interpreted differently by cultural groups. For example, in Saudi, Islamic clothes refer to white long garments, in Indonesia they refer to a dress with long sleeves and no collar (baju koko) together with sarong and black cap (peci).

The rise of the khati) to the podium with greeting of salarm (al-sala 'alaykum) marks the beginning of the Friday prayer ritual. This is then 
followed by the a call to prayer). At this time, Muslims come forward to fill the vacant spaces (s\&ff) to form rows facing Mecca (kiblat). According to my informant, God will give more reward to those praying at the first row. Besides, the Prophet urged Muslims not to leave space between members of the congregation as Satan will occupy that space and therefore disturb Muslims during prayer

The a $\gg$ is usually conducted by a mu'adhdbin who sits in the front row. This is not only done at Friday prayer but also at daily congregational prayer. At this point, the congregation bows their heads and listens to the a The content of the and and translation is provided by Henkel ${ }^{26}$ as follows:

\begin{tabular}{|c|c|}
\hline Alla akbar & God is great \\
\hline Alla akbar & God is great \\
\hline Alla akbar & God is great \\
\hline Alla akbar & God is great \\
\hline Asbhadu an la illa $\gg 1$ lla & $\begin{array}{l}\text { I know and affirm } \\
\text { without doubt there } \\
\text { is no god but God }\end{array}$ \\
\hline Ashbadu an la & $\begin{array}{l}\text { I know and affirm } \\
\text { without doubt }\end{array}$ \\
\hline Asbhadu anna Mubdmmadan Rasu৯Allaß & $\begin{array}{l}\text { Muhammad is God's } \\
\text { messenger }\end{array}$ \\
\hline Asbhadu anna Mubammadan RasuऽAlla & $\begin{array}{l}\text { Muhammad is God's } \\
\text { messenger }\end{array}$ \\
\hline Hdyya 'ala جl-splas & Come, to the splas \\
\hline Hábya 'ala al-splas & Come, to the splas \\
\hline Háyya 'ala al-falas & Come, to get victory \\
\hline Hádya 'ala $x$-falas & Come, to get victory \\
\hline Alla akbar & God is great \\
\hline Alla akbar & God is great \\
\hline La $\Rightarrow$ a illa $\gg$ Illa & No god but God \\
\hline
\end{tabular}

When the a $\rightarrow$ is announced, the congregation repeats what the mu'adhdhin has said with hushed voices. Fakhri explained that the

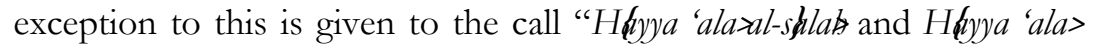

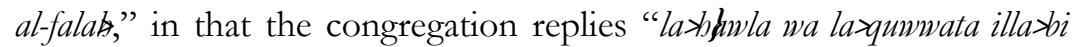

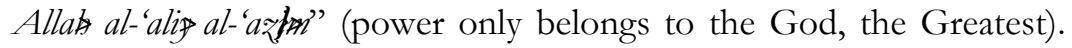

${ }^{26}$ Henkel, "Between Belief and Unbelief Lies the Performance of Salat," p. 494. 
My informant said the re-recitation of the a $a$ aby congregation is sunnah (recommended) and in doing so, Muslims may be rewarded (pabala) by God.

After the a praising God, sending blessings (sqlawa to the Prophet, followed by an exhortation to piety and recitation from the Qur'ars. This is conducted entirely in Arabic. The kbati $>$ then delivers a sermon in English. My informant says those who deliver kbutbah at ANUMA are students or lecturers at ANU and come from different countries: Indonesia, Malaysia, Saudi Arabia, and Pakistan, to name a few. Different khati deliver different topics addressing various aspects of Islam. Yet, the messages of the Friday sermon are generally inclined to be "more conservative than to be critical-liberal towards the existing tradition." 27 In this regard, the content of these sermons mostly encourages the congregation to be observant and good Muslims by following what God has commanded and avoiding what God has forbidden.

After completing the first sermon, the khati $>$ often takes a short rest by sitting on the podium seat while providing time for the congregation to recite their own prayer (du'a $>$. My informant says this is seen as the time in which God answers all the prayers from His servants. The khati $>$ then rises again to deliver a second, shorter kbutbah. Afterwards, he closes the khutbah by reciting the pillars of kbutlbah as he did at the beginning of the first sermon, and finally recites several prayers $\left(d u^{\prime} a\right.$ 子 asking God for the safety of Muslims in both the worldly life and the hereafter.

After the closing of the sermon, mu'adhdhin stands up once again to

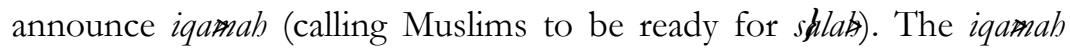

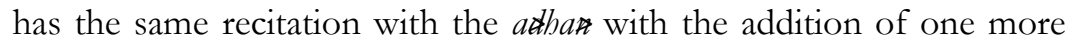
recitation, namely "qad qamat al-słlas" which means "indeed, prayer is established." It is recited twice between Hobya 'ala $\rightarrow$ l-falaAfand Alla Akbar. Another difference is that all lines of the a arsare announced once except Alla Akbar and La

\footnotetext{
27 Akh. Muzakki, "Islam as a Symbolic Commodity: Transmitting and Consuming Islam through Public Sermons in Indonesia," in Pattana Kitiarsa (ed.), Religious Commodifications in Asia: Marketing Gods (London and New York: Routledge, 2008), p. 214.
} 
iqa a the khati takes his position as prayer leader in front of the congregation. At this point, the members of the congregation stand, shoulder-to-shoulder and foot-to-foot, to form straight lines preparing for undertaking shlas

Before performing sdlas, the imam and congregation declare their intention to pray (nizah). According to my informant, every shla be preceded by declaring one's intention otherwise it will be invalid. The recitation of nizath, which is in Arabic, is adjusted to the sort of prayer. He said, for example, that the English version of nizath for Friday prayer is "I (as ima or ma'mu) intend to undertake two raka'als of the obligatory Friday prayer facing to kiblat (in Mecca) for the sake of Allah alone." Nizrab implies that Muslims are conscious and aware of their actions of prayer.

After declaring nizah, the imame, followed by congregation, starts sdla by pronouncing takbir saying "Allara Akbar", while raising his hands open on each side of the face and with his palms facing forward. After takbir $\rightarrow$ the hands are folded, the right palm is put over the left, against the front of the body. Raising his voice while the congregation keeps silent, the imarrecites the verses of al-fath (the opening) from the Qur'ar. Fakhri says that reciting al-fa th is an obligatory part of every sflas The English translation of the verses reads as follows:

"In the name of God, the Lord of Mercy, the Giver of Mercy! Praise belongs to God, Lord of the Worlds, the Lord of Mercy, the Giver of Mercy, Master of the Day of Judgment. It is You we worship; it is You we ask for help. Guide us to the straight path: the path of those You have blessed, those who incur no anger and who have not gone astray." 28

When the al-fath ends, the congregation responds in chorus: "aripl (accept our prayer!). The imam continues reciting another verse which is optional and not obligatory. Afterwards, ima and congregation bow (rukuPwhile reciting: "I praise my providence, who is Great and free from all defects." At this point, they bend placing their hands face down on their knees with fingers spread. After bowing, they stand while reciting "Allah has heard all who praise Him" and "our Lord: praise to Thee." They then go down to a kneeling and

${ }^{28}$ Haleem, A New Translation of the Qur'an, p. 3. 
prostrating position (suju reciting "Glory to my Lord, the most high." Rising from sujut they sit for a moment while reciting a particular prayer then bow again. After sujut the imand congregation stand again, bow and kneel. After the last kneeling, the ima and congregation sit and recite the utterance of reverence (tabis or witness-bearing (tashabhud). When tashabhud is pronounced, the ima and congregation raise their index finger as if they are pointing to the West. The tahis tashabhud consists of two parts; each translates as follows: ${ }^{29}$

(1) All reverence, all blessing, all sanctity are due to God. Peace be upon you, O Prophet, and the mercy of God and His blessings. Peace be upon us all and on the righteous servants of God. I bear witness that there is no God but Allah, and I bear witness that Muhammad is his Messenger;

(2) Oh, God! Exalt our Master Muhammad and the people of our Master Muhammad, as Thou didst exalt our Master Abraham and the people of our Master Abraham. And bless our Master Muhammad as the people of our Master Muhammad, as Thou didst bless our Master Abraham and the people of our Master Abraham. Verily, in the worlds, Thou art the praiseworthy, and glorious.

Finally, the ima closes prayer by turning his face to the right and the left while saying sala "peace be upon you and Allah's blessings." In this regard, sala constitutes the final part of the obligatory Friday prayer. After sala some devotees leave ANUMA, but most sit and recite wirid (a set of after-prayer invocations) as well as performing two raka'abs of voluntary słlał After prayer is over, many Muslims, especially Indonesians, choose to stay and have lunch from the Indonesian food provided at ANUMA. While having lunch, the Indonesian Muslims usually sit in circles and discuss their studies, personal and daily matters and issues from home, often spending one to two hours in conversation.

${ }^{29}$ A. G. Muhaimin, The Islamic Traditions of Cirebon: Ibadat and Adat Among Javanese Muslims (Canberra: ANU E-Press, 1995), pp. 98-99. 


\section{Social Significance of Friday Prayer}

This section is assigned to analysing the social meaning of Friday prayer for Indonesian Muslim students. It argues that the ritual is viewed by the participants as strengthening their Islamic faith and their membership of the Islamic Indonesian community in Canberra. Despite being a minority group, these Indonesian Muslims continue to maintain their faith and religious practices despite the influences of the prevailing Western culture. The act of prayer and associated social interactions reinforce their nationalist religious identity.

It is a challenge for Indonesian Muslims living in a secular country like Australia to maintain their behaviour as devout Muslims. In Australia, they have to face realities which are regarded as un-Islamic in their home country. According to Fakhri, when he first arrived in Canberra to study he was surprised to find many women wearing open and tight-fitting clothes and to see liberal interaction between men and women. He said that many foodstuffs forbidden to him as a Muslim such as pork, bacon and alcoholic drinks are sold at most shops and restaurants. As a result he has become very conscious of what he selects to eat and drink. According to Fakhri, Ramadhan (the fasting month) was difficult as he faced many temptations. However, with the passage of time Fakhri feels he has adjusted to living in Canberra.

Although a minority group in Canberra, many Indonesian Muslims maintain their Islamic traditions. They observe daily prayers and attend Friday prayers. They initiate pengajian (Islamic teaching) and celebrate Islamic holy days together. Fakhri and his Indonesian Muslim friends feel that their religious awareness has increased since moving to Australia as they now face the challenge of maintaining their Islamic faith in a non-Muslim majority country. I believe that Fakhri and his friends feel under threat from Western culture and lifestyles, which they see as potentially endangering of their Islamic faith. It is in this regard that Islamic rituals, including Friday prayer, play an important role in strengthening their Islamic faith and behaviour. To borrow Henkel's words, by regularly attending Friday prayer, the participants "seek to generate and maintain their capacity to submit willingly to what they see as the guidance offered by the Qur'aæ." 30

Participants do not focus much attention on the symbolism of the movements involved in Friday prayer. As discussed before, even

${ }^{30}$ Henkel, "Between Belief and Unbelief Lies the Performance of Salat," p. 489. 
Islamic scriptures and Muslim scholars themselves do not provide comprehensive meanings behind the movements of splas. My informant admits that he does not completely understand the meanings behind sdalabut the symbolism is not important for him. What is more important to him is to practice it in accordance with Islamic teaching. S dla for him, is like other forms of worship which represents devotion, dedication and submission to God. When praying he feels closer to God and this gives him calmness and the spirit to face worldly life. "On the Day of Judgment", he said, "God will give rewards to those who submit themselves to Allah by performing worship and good deeds."

In addition to strengthening their Islamic faith, Friday prayer serves to maintain membership of the Indonesian religious community. Indonesia has the largest Muslim population in the world, and scholars have asserted that Islam played an important role in the formation of Indonesian nationalism. ${ }^{31}$ In this regard, Islamic identity mixes with Indonesian national identity. Therefore, Friday prayer as an ordinary Islamic ritual in Indonesia plays a crucial role as an identity marker for Indonesian Muslims in Canberra. This stems from the fact that Friday prayer is a public ritual in which people can identify their fellow Muslims. Durkheim's theory argues that "religious representations are collective representations that express collective realities." 32 Or in other words, religion provides followers with a form of social cohesion. My informant said that he feels at home when he attends Friday prayer as he can meet fellow Indonesian Muslims. In this respect, the ritual of prayer is able to gather all Indonesian Muslims, especially those who study at ANU, in one place. Not only is Friday prayer a time of worship but also an opportunity to interact socially.

It is interesting to note that the Muslim congregation at ANUMA is divided into national groupings. This is most apparent when Muslims form small circles to have informal conversations before and after Friday prayer. Instead of using English, each group uses its own

\footnotetext{
${ }^{31}$ See Andi Faisal Bakti, Islam and Nation Formation in Indonesia: From Communitarian to Organizational Communications (Ciputat, Jakarta: Logos, 2000). See also Michael F. Laffan, Islamic Nationhood and Colonial Indonesia: the Umma below the Winds (New York: Routledge, 2003).

32 Emile Durkheim, The Elementary Forms of the Religious Life, Translated by Karen E. Fields (New York: The Free Press, 1995), p. 9. (The original work was published in 1912).
} 
national language, which tends to discourage others from joining in. At ANUMA, it appears that nationalistic solidarity outweighs global Islamic solidarity. Durkheim's theory on religion and social cohesion therefore does not completely describe the complexity of religious practice at ANUMA. Instead of cohesion, fragmentation occurs as each group tries to create the space of ANUMA as "home" for them.

From another anthropological perspective, the formation of religious identity through Friday prayer could be analysed especially within the relationship between the body and society. According to Bowie, particular identities could be formed and maintained through the use of symbols represented and performed by the body. ${ }^{33}$ In this respect, the body serves as a symbol and as an instrument that mediates between self and society. Humans belong to linguistic, ethnic, religious and cultural groups, and they may identify strongly with a religious, occupational, or lifestyle community. ${ }^{34}$ In the Islamic context for instance, to be a Muslim believer, it is not sufficient for one to declare shaba (there is one God, Allał, and that Muh łmmad is His Messenger). In addition, Muslims must also practice rituals which define being Muslim. Drawing on this perspective, the actions of Indonesian Muslim bodies performing Islamic rituals in congregation, therefore, form and maintain their connection to the Indonesian religious community.

Absence from Friday prayer may result in alienation from the Indonesian Muslim community. The position of Friday prayer is rather unique for Indonesian Muslims since they regard it as more important than the five daily prayers. As I have experienced in Indonesia, even nominal Muslims or abangans who rarely perform the five daily prayers always devote time go to the mosque to attend Friday prayer. It is common for Muslims who do not attend the Friday prayer three times to be judged by the community as hypocrites. Social pressures from Muslim neighbours and families may contribute to a Muslim attending Friday prayer. In this respect, the Islamic ritual of prayer may create and maintain Islamic identity for Muslims so that they can be acknowledged as a member of a devout Muslim group. My informant explained he had once been absent from Friday prayer because his

\footnotetext{
${ }^{33}$ Fiona Bowie, The Anthropology of Religion: An Introduction (USA: Blackwell Publishing, 2006), p. 62.

${ }^{34}$ Ibid.
} 
manager asked him to work that day. Many of his Indonesian friends criticised him for not attending the ritual. His friends said that the money he earned would not be blessed by God. The rebuke served to remind him as a 'good Muslim' he must attend Friday prayer. So while his decision to return to the ritual might appear religious, it also sets out to strengthen his membership within the Indonesian Muslim community in Canberra.

\section{Conclusion}

This paper has discussed the nature and position of sqlatsand Friday prayer in the light of Islamic doctrines as well as looking at the case of Friday prayer ritual at ANUMA in Canberra. It has analysed the social significance of ritual for Muslim participants drawing on the ethnographic methodologies of participant observation and in-depth interview. This paper has drawn three conclusions. Firstly, the sflas and Friday prayer have important positions in Islam, as they serve as acts of devotion to Islamic faith. Exploring Islamic doctrines, it is apparent that Islam emphasizes orthopraxy over orthodoxy. This is supported by the fact that the Prophet Muhammad has provided a model with detailed guidelines for Muslims in performing worship. Secondly, Friday prayer at ANUMA generally follows the same pattern as that seen in mosques in Indonesia. This suggests that Muslim obligatory worship represents a tradition inherited from the Prophet and his companions which does not allow for local modifications. In this regard, it cannot be compared to slametan, which is culturally based and has varied expressions and meanings through the Muslim world. Lastly, Friday prayer at ANUMA is viewed by Indonesian Muslim participants as the site for both strengthening Islamic faith in order to protect themselves from un-Islamic Western influences and creating and maintaining their Islamic and national identity. The social position of Muslim participants as a minority group who need to maintain their identity as 'Indonesian Muslims' contributes to support this analysis.

By studying the case of Friday prayer in Canberra, this paper suggests that although prescribed Islamic ritual is symbolically empty, it should be analysed within its social, historical, and political context to determine its "social significance." However, this is not to say that one meaning of particular worship in place and time, such as Friday prayer in Canberra, holds true for all Muslim minorities in Australia. A 
Muslim community's understanding and perception of an Islamic ritual is socially and culturally shaped.]

\section{Bibliography}

Ash Shiddieqy, T. M. Hasbi. Pedoman Shalat. Jakarta: Bulan Bintang, 1966.

Ayoub, Mahmoud M. Islam: Faith and History. Oxford: Oneworld, 2004.

Bachtiar, H. W. "The Religion of Java: a Commentary." Madjalab IlmuIlmu Sastra Indonesia, Vol. V, No. 1 (1973).

Bakti, Andi Faisal. Islam and Nation Formation in Indonesia: From Communitarian to Organizational Communications. Ciputat, Jakarta: Logos, 2000.

Bowen, John R. "Salat in Indonesia: The Social Meanings of an Islamic Ritual." in John R. Bowen (ed.). Religion in Culture and Society. Boston: Allyn and Bacon, 1998.

---------. Religions in Practice: An Approach to the Anthropology of Religion. Boston: Allyn and Bacon, 1998.

--------. "Imputations of Faith and Allegiance: Islamic Prayer and Indonesian Politics outside the Mosque." in David Parkin and S.C. Headley (eds.). Islamic Prayer across the Indonesian Ocean. UK: Curzon, 2000.

Bowie, Fiona. The Anthropology of Religion: An Introduction. USA: Blackwell Publishing, 2006.

Denny, Frederick M. "Islamic Ritual: Perspectives and Theories." in Richard C. Martin (ed.). Approaches to Islam in Religious Studies. Tucson, Arizona: University of Arizona, 1985.

Durkheim, Emile. "The Elementary Forms of Religious Life." in Michael Lambek (ed.). A Reader in the Anthropology of Religion. London: Blackwell, 2002.

--------. The Elementary Forms of the Religious Life. Translated by Karen E. Fields. New York: The Free Press, 1995. 
Graham, William A. "Islam in the Mirror of Ritual," in Graham William (ed.). Islam's Understanding of Itself. Malibu, California, 1983.

Geertz, Clifford. The Religion of Java. Chicago and London: The University of Chicago Press, 1967.

Haleem, Abdel. A New Translation of the Qur'an. New York: Oxford University Press, 2005.

Hawting, Gerald. The Development of Islamic Ritual. Great Britain: Ashgate, 2006.

Henkel, Heiko. "Between Belief and Unbelief Lies the Performance of Salat: Meaning and Efficacy of a Muslim Ritual." The Journal of Royal Anthropological Institute (N.S), No. 11 (2005): pp. 487-507.

Katz, Marion H. "The Study of Islamic Ritual and the Meaning of Wudu.” Der Islam, No. 82 (2005): pp. 106-145.

Laffan, Michael F. Islamic Nationhood and Colonial Indonesia: the Umma below the Winds. New York: Routledge, 2003.

Makris, G. P. Islam in the Middle East: A Living Tradition. Oxford: Blackwell, 2007.

Moller, Andre. "Islam and Traweh Prayers in Java: Unity, Diversity, and Cultural Smoothness." Indonesia and the Malay World, Vol. 33, No. 95 (2005): pp. 37-52.

---------. Ramadan in Java: The Joy and Jihad of Ritual Fasting. Lund, Sweden: Department of History and Anthropology of Religions Lund University, 2005.

Muhaimin, A. G. The Islamic Traditions of Cirebon: Ibadat and Adat Among Javanese Muslims. Canberra: ANU E-Press, 1995.

Muzakki, Akh. "Islam as a Symbolic Commodity: Transmitting and Consuming Islam through Public Sermons in Indonesia," in Pattana Kitiarsa (ed.). Religious Commodifications in Asia: Marketing Gods. London and New York: Routledge, 2008.

Nadwi, S. Abul Hasan Ali. The Four Pillars of Islam. India: Academy of Islamic Research and Publications, 1972. 
Rahman, Afzalur. Utility of Prayer. Lahore, Pakistan: Islamic Publications Ltd, 1974.

. Prayer: Its Significance and Benefits. Singapore: Pustaka Nasional, 1979.

Watt, W. M. What is Islam?. London and New York: Longman, 1979.

Woodward, Mark. Islam in Java: Normative Piety and Mysticism in the Sultanate of Yogyakarta. Tucson: The University of Arizona Press, 1989. 